\title{
The Impact of Service Quality on Customer Satisfaction: A Case Study on Nekemte Municipality, Oromia Region, Ethiopia
}

\author{
Abdissa Gemechu Gobena* \\ Department of Psychology, Nekemte College of Teacher Education, Ethiopia
}

Submission: July 22, 2019; Published: August 19, 2019

"Corresponding author: Abdissa Gemechu Gobena, Department of Psychology, Stream of Education, Nekemte College of Teacher Education, Post Box No. 88, Nekemte, Ethiopia

Abstract

Customer satisfaction and service quality are one of the basic opportunities, which help to run, to improve business and profit of the company, and especially save the loyalty of its customers. The main objective of this study was to assess the overall level of service quality and customer satisfaction in Nekemte Municipality and to investigate the impact of service quality dimensions on customer satisfaction under the study area. A conceptual model of service quality dimensions was developed. Data for this study was collected in Nekemte Municipality, which is situated in Oromia region, Ethiopia. This study was used both quantitative and qualitative research design and both primary and secondary data was employed. A total of 385 respondents taken as a sample customer of the Municipality were chosen and the questionnaires were distributed to customers of the municipal during office hours of the week. The collected data was analyzed with the help of SPSS version 23. Correlation and multiple regressions were used to investigate the relationship between dependent and independent variables.

The findings of the study show that service quality of customer satisfaction is below average, and customers are not satisfied with the service. Based on the finding all service quality dimensions have significant impact on service quality and customer satisfaction. The study concluded that over all service quality of Municipality is not good and customers are not satisfied with the services of Nekemte Municipality office employees. The researcher recommended that Nekemte Municipality land administration bodies should work hard on all these service quality dimensions to improve its service quality and customer satisfaction of Nekemte Municipality.

Keywords: Customer satisfaction; Service quality; Organization standards; Customer service delivery; Nekota municipality

\section{Introduction}

Customer Satisfaction and Service Quality are leading components in the system of external relations of each organization, as today they largely determine its competitiveness. The desire to manage relationships with customers leads to the fact that organizations are starting to pay attention to the development and implementation of service standards [1,2]. Quality is an important source of competitive advantage in service sector. Service quality is used to differentiate and add value to service offerings and to win strategic competitive advantage. New managerial methods explain quality as the customer satisfaction, for that reason all the organizations must recognize the high quality and quick service offering obstacles and solve them Ghasemi, kazemi and Esfahani (2012).

During the past few decades service quality has become a major area of attention to practitioners, managers and researchers owing to its strongimpact on customer satisfaction, business performance, customer loyalty, profitability and lower costs Guru (2003). However, providing high quality and cost-effective public services is not an easy task. It involves creating organizations with the right approaches, establishing clear ways of how to deliver services and putting the right people in place to respond to the needs of citizens. It also requires a combination of good policy development, successful implementation, a good understanding of citizens' needs and expectations, appropriate resources and technology, a

responsive organizational culture and well-trained staff [3]. At the same time, municipalities must balance the revenue they received with the high cost of providing more efficient services demanded by the citizen.

Customer satisfaction and Service quality are important concepts to academic researchers studying consumer evaluations and to practitioners as a means of creating competitive advantages and customer loyalty. Many industries are paying 
greater attention to customer satisfaction and service quality, for reasons such as increased deregulation and competition Ghasemi, kazemi and Esfahani (2012). Satisfaction from service quality is frequently evaluated in terms of functional quality and technical quality Gronroos (1984). Regularly, customers do not have lot information about the technical phases of a service; therefore, functional quality becomes the main aspect from which to form perceptions of quality of service. Service quality may be described as customer perception of how well a service assembles or go over's their expectations. Service quality can be determined 2 in terms of customer expectation, customer perception, and customer attitude and customer satisfaction [4].

Cities are important role players in service delivery Boshoff, Mazibuko (2008). They are required by law to find innovative methods to involve communities in all their affairs. The mandate of a Municipality, according to the Constitution, is to ensure that the service deliveries for which it is responsible satisfy citizens" basic needs. These include water supply, sewerage collection and disposal, refuse removal, electric municipality and gas supply, health services, roads and storm water drainage, street lighting, and municipal parks and recreation Boshoff \& Mazibuko (2008).

Quality in service is very important especially for the growth and development of service sector business enterprises [5]. It works as a factor of customer satisfaction Ruyter and Bloemer (1995). With the increase of the importance of service sector in Ethiopian economy, the measurements of service quality become important. Many studies indicate that there are links between customer satisfaction and service quality. In order to meet customer demand, many companies need to better serve their customers. Better quality of service can usually get a higher market share and better returns slu \& mou (2003). Providing excellent customer satisfaction and high service quality is the significant matter and challenge meeting the current service industry Hung (2003). Customer satisfaction and service quality have been for this latest year's important topic both for the researches in the field of logistics and transportation for the academic and problem-solving purpose. Because of high market competition service quality becomes an increasingly important issue in the field of competitive market. Therefore, these issues become very important to satisfy the customerBroderick \& Vachirapornpuc, (2002). Therefore, the main purpose of this study was to investigate the impact of services quality on overall customer satisfaction in Nekemte Municipality

\section{Statement of the Problem}

One of the most significant challenges facing services organizations today is to provide consistently high-quality services. The delivery of consistent service quality is arguably the most vital factors that contribute to the establishment of credibility and reputation of the organizations in the eyes of the public. It is well recognized that providing high quality services has a beneficial effect on the bottom-line performance for the organization. Indeed, there is a growing body of empirical evidence indicating that providing top quality services enhances profitability, improves productivity, spreading positive word-ofmouth, increases market share and return on investment, and reduces costs [5].

Like many other services organizations, public services organizations specifically those ones operating at local government level, are not immune to the pressures to improve the quality of their services on a continuous basis. Municipal authorities for example, face more daunting tasks than those in the private sector in their efforts to provide excellent service and maintain citizen satisfaction. A wide variety of influences is effectively bringing about awareness of quality issues, and of concepts such as quality management. Some of these influences arise directly from local authorities' genuine desire to enhance their public image by improving the quality of those services provided to the community, while others come "imposed" or "forced" either by means of public initiatives or through an increase in consumers' awareness of their rights Vázquez, Gutiérrez \& García (2005).

Despite services being a large and important segment of the world economies, the concepts and practice of service quality and service delivery are less developed compared to those concerning quality in the manufacturing industry Ghobadian, Speller \& Jones (1994); Douglas \& Fredendall (2004). Service organizations are lagging their manufacturing counterparts in terms of the effective use of Total Quality Management (TQM) practices aimed at achieving organizational objectives Yasin, Alavi, Kunt \& Zimmerer (2004).

Several studies have been done on service quality using SERVQUAL in different service sectors. Fick and Ritchie (1991) provide an initial application of SERVQUAL in the airline industry and illustrate how the measurement approach can be useful in comparing different components of a larger service sector (in their case, the tourism industry). A similar project has been conducted by Pakdil and Aydin (2007), who developed a modified version of SERVQUAL, which extended the original service quality dimensions to include issues of image, flight experience and availability of interchange, with airline passengers tending to rate responsiveness as the most important service dimension. Negi [6] used the model to determine customer satisfaction through perceived quality in the Telecommunication industry and found out that reliability, empathy and network quality proved to significantly effective in contributing to overall service quality and overall customer satisfaction with mobile services.

In context of hotel Akan, (1995) used the SERVQUAL model in the four stars hotels and found out that competence and courtesy combined with assurance where most important attributes influencing the perception of quality. In our country Ethiopia, G/ egziabher $\pi / 2$ (2015) examined the service quality and customers' satisfaction in hotel industry in Addis Ababa, Ethiopia on threestar hotels stated that the combination of tangibility, reliability, responsiveness, confidence and communication together has significant and positive effect on customer satisfaction. And, the 
hotel guests' perceptions of service quality provided by the hotel industry were lower than their expectations.

Furthermore Andargie (2013) conducted a study on foreign customer satisfaction in Ethiopian five-star hotels Sheraton Addis and Hilton intercontinental hotels reported that foreign customers are not satisfied by the services of the hotels, more over all services quality dimensions created a gap in their expectation and perception of guests. Besides Zeleke (2012) has examined a study about the impact of service quality on customer satisfaction at the public owned National Alcohol and Liquor Factory stated that the five service quality dimensions brought an impact on customer satisfaction was significant in all factors of service quality. Finding by Shimekit Kelkay Eshetie, Wondoson Seyoum \& Seid Hussen Ali (2016) on of Selected Hotels in Nekemte Town, Ethiopia also showed that there was a negative gap between actual service and expected service in all dimensions of lodging quality index and significant and positive relationships of five service quality dimensions and customers satisfactions.

Cummane \& Conn [7] make a notion stating that despite customer satisfaction has raised concerns in the contact center industry; empirical studies have mostly been conducted on staff dissatisfaction rather than customer satisfaction. The relationship of service quality, service quality dimensions and customer satisfaction are also relevant in examining the conditions under the study area. Similarly, in Jimma Town in banking industry, Fikadu (2013) conducted research on customer satisfaction and service quality. And he conducted his study through qualitative method, the result indicates that Commercial bank of Ethiopia faces various problems especially regarding quality service and he recommended in his paper to carry out research in similar area to generalize the issues in Commercial bank of Ethiopia. So, the researcher wanted to assess the impact of service quality on customer satisfaction in the case of Nekemte Municipality. In this study, there are few questions have been generated to answer the following questions about the service quality dimension (SERVQUAL) and customer satisfaction.

Based on the identified research problems, this study tried to answer the following questions.

a) What is the impact of service tangibility, reliability, responsiveness, assurance, and empathy on customer satisfaction Nekemte Municipality in land administration \& manage office?

b) Which dimensions are the best predictors of overall service quality perceived by the customers Nekemte Municipality in land administration \& management office?

\section{Objectives of the Study}

The major objective of this study was to investigate the result of services quality on overall customer satisfaction Nekemte Municipality in land administration \& management office, west of Oromia regional State. The specific objective of this study was to; a) Investigate the impact of service tangibility, reliability, responsiveness, assurance, and empathy on customer satisfaction Nekemte Municipality in land administration \& management office.

b) Identify which is the best SERVQUAL dimension perceived by the customer Nekemte Municipality in land administration \& management office.

\section{Significance of the Study}

The outcome of this study Service delivery and service quality, determined by the disparity between the expectations of the community and its perceptions of the service delivered can provide an organization with a lasting competitive advantage.

Specifically, this study will be significant in the following ways:

a) The study will help the government and other sector players to devise means for which the sector can maximize its customer satisfaction by providing customers service quality.

b) The study will add a body of knowledge from which more other researchers will be attracted to engage in the same issue or other issues of concern in service delivery.

c) It may also be helpful for Nekemte municipality administration to take corrective measures like awareness creation about customer service delivery improve the performance of the management committees through education, training, and information so as to overcome the challenges constraining in delivery of customer service to make members aware about the possible prospects.it is essential for researchers who want to undertake further studies related to the institutions service.

\section{Literature Review}

Research on services quality has currently received special attention from marketing researcher. Some research conducted on quality services and its effect on customer satisfaction and their results are summarized as follow: - There are many research works done related with this study. However, the researcher tries to see three of them which are more related to the topic. The titles with their objectives and major findings are discussed below to have an insight about these studies.

The first work is MBA thesis done by Aman (2008) with title of "Effects of service delivery process and service quality on customer satisfaction: a case study of EEPCO, North Western region, Bahir Dar town customer service centers". The main purpose of the study is to examine the effect of service delivery process and service quality on satisfaction of customers of EEPCO with the following specific objectives: To examine the effect of service delivery process and service quality on customer satisfaction and to understand real situation on how EEPCO handle its customers.

On the relationship between customer satisfaction and service quality. Research was conducted in a bank in Tehran, Iran by Osman Mohammad; et.al (2010) revealed that service quality 
would be one of the determinants of satisfaction. The finding that nearly 43 percent of customer"s satisfaction changes is explained by service quality. On the relationship between Bank Service Quality, Customer Satisfaction in Ethiopian Banking Sector, Messay (2012) concluded that all service quality dimensions are positively correlated with customer satisfaction indicating $90.7 \%$ of the variance in customer satisfaction can be predicted by the service quality offered by the private banks. In addition, results of this research show that there is a positive significant relationship between customer satisfaction and loyalty and explain $62 \%$ of the variance.

On the relationship between Service quality, satisfaction, perceived value among customers in commercial banking in Nakuru Municipality, Kenya, Daniel O. Auka (2012) concluded that service quality and customer satisfaction were positively and significantly associated indicating $19.8 \%$ of the variance in customer satisfaction can be predicted by the service quality offered by the commercial banks.

\section{Service quality}

Service quality is a concept that has attracted considerable interest and debate in the marketing literature because of the difficulties in both defining it and measuring it with no consensus emerging on either $[1,2]$. One that is commonly used defines service quality as the ability of the organization to meet or exceed customer expectations. It is the result of the comparison between customers' expectations about a service and their perception of the way the service has been performed [8]. If expectations are greater than performance, then perceived quality is less than satisfactory and hence customer dissatisfaction occurs [9].

Most of the recent work on service quality in marketing can be credited to the pioneering and continuing work of Parasuraman, Berry \& Zeitham [9]. In a seminal research study [8], identified ten dimensions of service quality based upon a series of focus groupstudies.

These dimensions are:
a) tangible features
b) reliability
c) responsiveness
d) communication
e) credibility
f) security
g) competence
h) courtesy
i) understanding
j) access

From that initial research, Parasuraman etal. (1988) developed a service quality instrument called SERVQUAL that consisted of 22 pairs of statements, which measure customer expectations and perceptions of service delivered on a seven- or nine-point Likert scale. For each pair of statements, the gap difference between the two scores is calculated. The idea is that the service is good if perceptions meet or exceed expectations and problematic if perceptions fall below expectations. The scale combined ten components into five generic dimensions of service quality, which they claimed, "provides a basic skeleton which can be adapted or supplemented to fit the characteristics or specific research needs of a particular organization". These dimensions "captures facets of all ten originally conceptualized dimensions" regardless of service industries (Zeithaml et al., 1990, p. 26). These dimensions are defined as follows:

\section{Tangibles}

The definition of tangibility is the appearance of physical facilities, equipment, personnel and communication materials Santos (2002). Tangibility provides physical representations or images of the service that customers, particularly new customers, will use to evaluate quality. Service organizations often use tangibles to enhance their image, provide continuity and signal quality to customers. In contrast, organizations that do not pay attention to tangibility dimensions of the service strategy can confuse and even destroy a good strategy Wilson et al., (2008).

Owing to the intangible nature of services, it is often difficult for customers to understand and evaluate services and, therefore, customers often rely on the tangible evidence that surrounds the service in forming evaluations Jamal \& Anastasiadou (2009). The tangibility dimension of SERVQUAL compares customer expectations to customer perceptions regarding the organization's ability to manage its tangibles. Comparing the perception scores to the expectation scores provides a numerical variable that indicates the tangibles gap $[10,11]$.

\section{Reliability}

The reliability dimension of service quality refers to the ability of service organizations to perform the promised service dependably and accurately, and thus reflects the consistency and dependability of an organization's performance Rodriques, Bonar \& Sacchi (2011). Wilson et al. (2008) state that reliability means that the organization delivers on its promises about service delivery, service provision and problem resolution. Even though unreliable service providers are extremely frustrating for customers, a disturbing number of organizations still fail to keep their promises regarding service delivery. In many instances, the customer is ready to spend money if only the service provider will show up and conduct the transaction as promised Bateson \& Hoffman (2011). Reliability is consistently the most important determinant of perceptions of service quality Wilson, Zeithaml, Bitner \& Gremler, (2008).

\section{Responsiveness}

Responsiveness is the willingness to help customers and to provide prompt service Jamal \& Anastasiadou (2009). This 
dimension emphasizes attentiveness and promptness in dealing with customer requests, questions, complaints and problems. Responsiveness also captures the notion of flexibility and the ability to customize the service to customer needs. The organization must view the process of service delivery and the handling of requests from the customer's point of view rather than from the organization's point of view Wilson et al. (2008). Responsiveness reflects a service organization's commitment to provide services in a timely manner. As such, the responsiveness dimension concerns the willingness and readiness to provide a service. Occasionally, customers may encounter a situation in which employees are engaged in their own conversations with one another while ignoring the needs of the customer $[10,11]$.

\section{Assurance}

The assurance dimension of service quality addresses the competence of the organization, the courtesy it extends to its customers and the security of its operations. Jamal and Anastasiadou (2009) define assurance as employees" knowledge and courtesy, and the ability of the organization and its employees to inspire trust and confidence. Bateson \& Hoffman [10,11] add that competence pertains to the organization's knowledge and skills in performing the promised service and refers to how the organization's employees interact with the customer and the customer's possessions. Wilson et al. (2008) warn that this dimension is likely to be particularly important for services that customers perceive as high risk or for services that customers feel uncertain about their ability to evaluate the outcomes.

\section{Empathy}

Jamal and Anastasiadou (2009) define empathy as the caring and individualized attention that the organization provides its customers. Bateson \& Hoffman $[10,11]$ explain that empathy is the ability to experience another's feelings as one's own. According to Wilson et al. (2008), the essence of empathy is conveying, through personalized or customized service, that the customers are unique and special and that their needs are understood. Empathetic firms have not lost touch with what it is like to be a customer of their own organization. Assuch, the organization understands customers" needs and makes their services accessible to their customers. In contrast, organizations that do not provide the requested individualized attention totheir customers and offer, for example, operating hours convenient for the organization and not its customers, fail to demonstrate empathetic behavior $[10,11]$.

\section{Customer Satisfaction}

Customer satisfaction has been recognized as one of the most important elements of contemporary marketing thought, particularly in the case of service sectors Bejou, Ennew \& Palmer (1998) and one of the main goals in marketing Erevelles \& Leavitt (1992). Because satisfied customers tend to maintain their consumption pattern or consume more of the same product or service, customer satisfaction has become an important indicator of the future behavior McQuitty, Finn \& Willey (2000). Due to its centrality, various theories and models have been developed in an effort to define the construct and explain satisfaction in different products/services and consumption stages for a review, see Erevelles \& Leavitt, (1992).

Studies in services marketing have shown that service quality and customer satisfaction are closely related. Services marketers are involved in substantial campaigns to improve the quality of their organizations" services and profitability by ensuring customer satisfaction Woodruffe (1995:293). According to Zeithaml et al. (2008:103), customer satisfaction is a broad concept, whereas service quality focuses specifically on the dimensions of services and, therefore, perceived service quality is a component of customer satisfaction. According to Noone and Namasivayam (2010:273) and Palmer (2011:288), there is a strong relationship between customer satisfaction and service quality. Customer satisfaction affects assessments of service quality and assessments of service quality affect customer satisfaction.

\section{Measuring service quality}

According to Dhurup (2003:66), receiving a high level of service is important to customers but understanding how to measure and evaluate the service quality received is challenging. A reliable measure of service quality is critical for identifying the aspects of service needing performance improvement, measuring the degree of improvement needed on each aspect and evaluating the impact of improvement efforts Zeithaml et al., (2008:151). Seth and Deschmukh (2005:913) believe that for an organization to gain a competitive advantage, marketers must collect information on market demand to enhance service quality. Zeithaml et al. (2008:151) warn that unlike products quality, which can be measured objectively by indicators such as durability and number of defects, service quality is abstract and is best captured by surveys that measure customer evaluations of service.

\section{Service quality model}

Given the complex nature of service quality, it is not surprising that there have been divergent views about the most suitable way to conceptualize and measure it Palmer (2011:293). Much of the research still uses some variant of the disconfirmation paradigm to measure customer satisfaction. Disconfirmation holds that satisfaction is related to the size and direction of the disconfirmation experience, where disconfirmation is related to the person's initial expectations. A customer's expectations are positively confirmed when a service performs as expected and negatively disconfirmed when the product or a service performs better than expected Churchill \& Suprenant (1982:493).

\section{SERVQUAL model}

The SERVQUAL model, developed by Parasuraman [9], is a measurement model for service quality that has been extensively applied in many studies focusing on service quality assessment Zeithaml et al., (2008:154). Zeithaml et al. (2008:151) add that the SERVQUAL model is one of the first measures to be developed specifically to measure service quality. The SERVQUAL instrument is known to be the predominant method used to 
measure customers" perceptions of service quality Lewis \& Booms, 1983:100). Boshoff and Du Plessis (2009:43) believe that this model is arguably, the best-known instrument to measure customers" perceptions of service quality. According to Jabnoun \& Khalifa [12], the popularity of the SERVQUAL is because of the various advantages the model offers, namely that it:

a) Is accepted as a standard for assessing different dimensions of service quality

b) Is shown to be valid across various service industries

c) Has demonstrated reliability in that different respondents interpret the questions similarly

d) Is parsimonious in that it has a limited number of items and therefore it can be completed quickly

e) Has a standardized analysis procedure to aid in the interpretation of results.

The SERVQUAL model views service quality as the gap that exists between customer expectations and perceived performance. The model suggests that the greater the distance between the two variables where performance supersedes expectations, the greater the service quality Crick \& Spencer, (2011:467). Wilson et al. (2008:132) have identified the following purposes of the SERVQUAL model:

a) Through identifying differences between customers" perceptions and expectations, service organizations may identify average gaps for each service attribute.

b) The five SERVQUAL dimensions may be used to assess the service organization's service quality.

c) Service organizations may monitor customers" perceptions and expectations using individual service attributes or the SERVQUAL dimensions.

d) Service organizations may compare the service quality ratings against those provided by competing organizations.

e) The service organization's service performance measurements may be used to identify and examine differences in customer segments.

f) The SERVQUAL model may be used to measure the internal service quality offered by the service organization's departments or divisions.
The SERVQUAL instrument involves a scale consisting of two sections, each of which contains 22 service attributes, grouped into the five service quality dimensions, namely tangibility, reliability, responsiveness, assurance and empathy Cram (2001:266). The model was designed to measure customers" expectations and perceptions of service quality. The first section of the instrument consists of perception items followed by expectation items Boshoff\& du Plessis (2009:45). Comparing the customers" expectations before a service encounter and their perceptions of the actual service delivered has been the most often used approach for measuring service quality Lewis \& Booms (1983:100). The conceptualization, dimensionality, operationalization, measurement and applications of the SERVQUAL model have been subjected to some criticisms, which include the dimensions (reliability, assurance, tangibility, responsibility and empathy) [13].

\section{Materials and Methods}

The research design for this study was explanatory research cross sectional design or the purpose of collected data using questionnaire. The research design is appropriate in this study because it ensured in-depth analysis and description of the various phenomena under investigation. The study involved dominantly quantitative supported by qualitative data [14].

\section{Target population}

Target population was the group of people where researcher was interested in analyzing to get relevant information for research purpose. The population refers to the entire group of people, events, or things of interest that the researcher wishes to investigate. The population for this study were some selected customers of Nekemte Municipality especially who utilized land administration office. The population was included some selected residents of Nekemte town who have been visited to the office of the Municipality for their interest. Therefore, customers who visited the office during the data collection period was selected to be part of the study [15].

\section{Sample size and sampling techniques}

The researcher used multistage sampling to select representative of customers' residents in Nekemte Municipality. Cochran (1975) sample size determination formula was used to decide the sample size.

The detail sampling size for the study is presented in (Table 1) below [16].

Table 1: Summary of Samples size of population for the Study (2019).

\begin{tabular}{|c|c|c|}
\hline Kebele Selected for the Study & Sample Residents & Kebele Administers of Municipality \\
\hline Celeleki kebele & 64 & 2 \\
\hline Burka Jato kebele & 64 & 2 \\
\hline Darge kebele & 64 & 2 \\
\hline Bekansa Kese kebele & 64 & 2 \\
\hline Beke Jama Kebele & 64 & 2 \\
\hline
\end{tabular}




\begin{tabular}{|c|c|c|}
\hline Keso kebele & 65 & 2 \\
\hline Sub Total & 385 & 12 \\
\hline
\end{tabular}

\section{Instrument of data collection}

The tools used to collect data include survey questionnaires, discussion with key stakeholders, meetings with beneficiary communities and program implementers. Data were collected from selected participants through interviews administered by the research and a research assistant using a standardized questionnaire with both close ended and open-ended questions which are given to respondents to give their views about the study topic. Open ended questions are used in order to allow respondents personal views and closed questions are used to captivate the respondents. The instrument was pilot tasted for its content validity and reliability. The reliability of the total instrument was .79. The subscales reliability was $0.84,0.77,0.79$, 0.77 , and 0.79 for reliability, responsiveness, tangibility, assurance and empathy respectively. The result of 0.7 and above implies an acceptable level of internal reliability as suggested by Hair et al. (2003).

\section{Method of data analysis}

The study used descriptive data analysis which combines both quantitative and qualitative data methods of analysis. After data collection quantitative data were organized, coded, tabulated and checked for appropriateness and analyzed using SPSS version 23. The descriptive statistical tools such as mean, frequency, standard deviation and percentages through SPSS plus Pearson product correlation coefficient was also applied to investigate the relationship among variables. Multiple regression analysis was used to investigate the effect of service quality dimensions (Tangible, reliability, responsiveness, assurance, empathy) and customer satisfaction. The statistically significant was tested at the .05 level. The data obtained through open ended questions and interview guides were analyzed qualitatively by summarizing their words as a supplement to quantitative data $[17,18]$.

\section{Results and Discussion}

\section{Characteristics of respondents}

The demographic characteristics of the respondents include gender; age maternal status and level of education were indicated in (Table 2). The sample comprised of $56.6 \%$ male and $43.4 \%$ female customers, $47.8 \%, 35.1 \%, 14.5 \%$ and $2.8 \%$ of the sampled customers ranges from 31-40years, 25-30years, 18-24 years and above 41years consecutively. While $63.9 \%, 29.3 \%$ and $6.8 \%$ of the sampled respondents were married, single and divorce respectively. Regard to educational level; the entire respondents were below diploma holder $29.1 \%$ and a diploma holder comprises $15.6 \%$ of the customer. While degree holder is comprising $41.3 \%$ and consists of having second degree holder comprises 14.02 [19].

Table 2: Characteristics of Respondents.

\begin{tabular}{|c|c|c|c|}
\hline \multirow{4}{*}{ Variables } & \multicolumn{2}{|c|}{ Frequency } & Percent \\
\hline \multirow{3}{*}{ Sex } & Male & 231 & 56.6 \\
\cline { 2 - 4 } & Female & 154 & 43.4 \\
\hline \multirow{3}{*}{ Age } & $18-24$ & 56 & 14.5 \\
\cline { 2 - 4 } & $25-30$ & 135 & 35.1 \\
\cline { 2 - 4 } & $31-40$ & 184 & 47.8 \\
\hline \multirow{3}{*}{ Maternal } & Above 41 & 10 & 2.8 \\
\cline { 2 - 4 } & Married & 247 & 63.9 \\
\cline { 2 - 4 } & Single & 114 & 29.3 \\
\hline \multirow{3}{*}{ Education } & Divorced & 24 & 6.8 \\
\cline { 2 - 4 } & $<$ Diploma & 112 & 29.1 \\
\cline { 2 - 4 } & Diploma & 60 & 15.6 \\
\hline
\end{tabular}

\section{Analysis of quality dimensions}

(Table 3) shows on the 5-point Likert scale the reliability item that the response with the $(M=2.26, S D=0.87)$. This indicates that the mean averages below 3 shows customers were not satisfied with most of the items under reliability. Regarding to responsiveness, tangibility, assurance, and empathy the mode value for $(M=2.54, S D=0.89),(M=2.71, S D=0.94),(M=2.86$, $\mathrm{SD}=0.72)$ and $(\mathrm{M}=2.68, \mathrm{SD}=0.91)$ respectively [20]. This shows customers were not satisfied with most of the items under the all service quality dimensions. Thus, from he analyzed data and obtained information the researcher concludes that customers those samples selected were not satisfied by the service delivery of Nekemte Municipality. 
Annals of Social Sciences \& Management studies

Table 3: Respondents views for Service Quality Dimensions.

\begin{tabular}{|c|c|c|c|}
\hline No & Service Quality Dimensions & Mean & Std. \\
\hline \multicolumn{4}{|c|}{ Reliability } \\
\hline 1 & When the organization promises to deliver within a given time, it does so & 2.36 & $\begin{array}{c}0 . \\
89\end{array}$ \\
\hline 2 & The organization services are always available as and when required by the customer & 2.31 & $\begin{array}{c}0 . \\
76\end{array}$ \\
\hline 3 & The employees show sincere in solving customers' concern & 2.50 & 0.87 \\
\hline \multirow[t]{2}{*}{4} & The organization able to perform the service right first Time & 2.69 & 0.98 \\
\hline & Total & 2.47 & 0.87 \\
\hline \multicolumn{4}{|c|}{ Responsiveness } \\
\hline 5 & employees are happy and willing to serve customers & 2.39 & 0.89 \\
\hline 6 & Employees tell customers exactly when services will be Performed & 2.59 & 0.90 \\
\hline 7 & The management are accessible, listen and provide prompt and honest responses to customers inquiries & 2.62 & 0.93 \\
\hline \multirow[t]{2}{*}{8} & The employees are not too busy to respond to user requests & 2.55 & 0.84 \\
\hline & Total & 2.54 & 0.89 \\
\hline \multicolumn{4}{|c|}{ Tangability } \\
\hline 9 & The company has visually appealing physical facilities & 2.69 & 0.95 \\
\hline 10 & The employees are well dressed and neat in appearance & 2.94 & 0.94 \\
\hline \multirow[t]{2}{*}{11} & The material associated with the service for example training manuals are visually appealing & 2.50 & 0.92 \\
\hline & Total & 2.71 & 0.94 \\
\hline \multicolumn{4}{|c|}{ Assurance } \\
\hline 12 & The support staff have the required skills to resolve problems and answer questions & 2.72 & 0.98 \\
\hline 13 & The employees make customers feel safe in their service delivery & 3.20 & 0.68 \\
\hline \multirow[t]{2}{*}{14} & The employee is consistently courteous to the customers interest & 2.65 & 0.49 \\
\hline & Total & 2.86 & 0.74 \\
\hline \multicolumn{4}{|c|}{ Empathy } \\
\hline 15 & The employees give customers individual attention & 2.88 & 0.96 \\
\hline 16 & The employees are committed to ethics and promote ethical behavior in the workplace & 2.83 & 0.88 \\
\hline 17 & Services are adjusted to suit individual customer needs & 2.52 & 0.86 \\
\hline \multirow[t]{2}{*}{18} & The operating hour are convenient to all customers & 2.48 & 0.92 \\
\hline & Total & 2.68 & 0.91 \\
\hline
\end{tabular}

\section{Statically analysis of customer satisfaction}

\section{Satisfaction item}

Thus, as presented in (Table 4). the mean value is between 2.35 and 2.49. except item number four all attribute of frequency showing majority of respondent disagree with customers' overall satisfaction with the organization employees service provider. Having a higher standard deviation, using the mode value will be more realistic in deterring the most frequently occurring response. Thus, from he analyzed data and obtained information we can conclude that customers those samples selected were not satisfied by the service delivery of Nekemte Municipality particularly on the delivery and service of land administration \& management office.

\section{Pearson correlation analysis}

To determine the relationship between service quality dimensions (Tangibility, Reliability, Responsive, Assurance, and
Empathy) and customer satisfaction, Pearson correlation was computed. The results of Pearson correlation on the relationship between service quality dimension and customer satisfaction indicated in (Table 5). According to the (Table 5), there is a significant positive relationship between the five dimensions of service quality and customer satisfaction, the relatively the highest correlation is between responsiveness and customer satisfaction (0.788) followed by reliability (0.768), empathy (0.699) and the remaining dimension tangibility and assurance (0.673) and (0.659) respectively. Relatively the weakest correlation is between assurance and customer satisfaction whereas; the strongest correlation is between responsiveness and customer satisfaction [21]. In general, if correlation is positive between two or more variables that is, when service quality dimensions and customer satisfaction is positively related; delivering better service quality ensures higher customer satisfaction. Accordingly, the most important service quality dimension that affects 
customer satisfaction is responsiveness, which goes to prove that responsiveness perceived as a dominant service quality followed by reliability; This indicates improvement in fast service and reliable service have significant effect on customer satisfaction levels with

Table 4: Analysis of customer satisfaction.

\begin{tabular}{|c|c|c|}
\hline Customers Satisfaction & M & SD \\
\hline Customers' overall satisfaction with the organization employees service provider & 2.35 & 1.185 \\
\hline Customers intention for renewal of their contract with their organization employees service provider & 2.30 & 1.074 \\
\hline Customers consideration of the image of their organization employees service provider for the renewal of their support contract & 2.49 & 1.040 \\
\hline $\begin{array}{c}\text { The organization able to perform the service right first time Customers consideration of price for renewal of their organization } \\
\text { employees' services }\end{array}$ & 2.69 & .985 \\
\hline Customers consideration of Timeline of the service for renewal of their contract with organization employees service provider & 2.49 & 1.040 \\
\hline
\end{tabular}

Table 5: Relationship between customer satisfaction and five service quality dimensions. ${ }^{* \star}$. Correlation is significant at the 0.05 level (2-tailed). Source: SPSS Correlation result output, 2019.

\begin{tabular}{|c|c|c|c|c|c|c|}
\hline Service Quality (Indep.) & Reliability & Responsiveness & Tangibility & Assurance & Empathy & Customer Satisfaction \\
\hline Reliability & 1 & & & & & \\
\hline Responsiveness & $.751^{* *}$ & 1 & & & & \\
\hline Tangibility & $.256^{* *}$ & $.367^{*}$ & 1 & & & \\
\hline Assurance & $.313^{* *}$ & $.431^{*}$ & $.367^{*}$ & 1 & & \\
\hline Empathy & $.658^{*}$ & $.719^{*}$ & $.498^{*}$ & $.464^{*}$ & 1 & \\
\hline Customer Satisfaction (dep.) & $.768^{*}$ & $.788^{*}$ & $.673^{*}$ & $.659^{*}$ & $.699^{*}$ & \\
\hline
\end{tabular}

\section{Multiple regression analysis}

Multiple regressions are the most common and widely used to analyze the relationship between a single continues dependent variable and multiple continues categorical independent variable George et al, (2003). In this study multiple regression analysis the same analogy improving staffs knowledge, over all behavior and way of delivering service also have significant effect. Even if, tangibility and assurance have weakly correlated improving these dimensions has also effect on customer satisfaction.

Table 6: Summary of Standard Multiple Regression Analysis Source: SPSS Regression results output, 2019.

\begin{tabular}{|c|c|c|c|c|c|c|c|c|}
\hline \multirow[t]{2}{*}{ Model } & \multicolumn{2}{|c|}{ Unstandardized Coefficients } & \multirow{2}{*}{$\begin{array}{c}\text { Standardized Coefficients } \\
\text { Beta }\end{array}$} & \multirow[t]{2}{*}{$\mathbf{t}$} & \multirow[t]{2}{*}{ Sig. } & \multirow[t]{2}{*}{$\mathbf{R}$} & \multirow[t]{2}{*}{$\mathbf{R 2}$} & \multirow[t]{2}{*}{ Adjusted R2 } \\
\hline & $\mathrm{B}$ & Std. Error & & & & & & \\
\hline (Constant) & -.318 & .136 & & 2.338 & .020 & $.786 a$ & .618 & .612 \\
\hline Reliability & .218 & .057 & .201 & 3.836 & .000 & & & \\
\hline Responsiveness & .276 & .067 & .234 & 4.095 & .000 & & & \\
\hline Tangibility & .172 & .049 & .137 & 3.511 & .001 & & & \\
\hline Assurance & .483 & .064 & .409 & 7.524 & .006 & & & \\
\hline Empathy & -.087 & .031 & -.107 & -2.766 & .000 & & & \\
\hline \multicolumn{9}{|c|}{ A. Dependent Variable: Customer Satisfaction. } \\
\hline B. Predictors:(Con & thy, A & igibility, Re & bility, Responsiveness. & & & & & \\
\hline
\end{tabular}

(Table 6) shows the standardize beta coefficient, which tell us the unique contribution of each factor to the model. A high beta value and a small $\mathrm{p}$ value $(<.005)$ indicate the predictor variable has made a significance statistical contribution to the model. On the other hand, a small beta value and a high $\mathrm{p}$ value ( $\mathrm{p}$ $>$.005) indicate the predictor variable has little or no significant contribution to the model. Ggorge et al. (2003). The results indicate that tangibility, reliability, responsiveness, assurance and empathy dimension of service quality have a significant influence was employed to examine the effect of service quality dimensions on customer satisfaction. The following (Table 6) presents the results of multiple regressions analysis. Here the squared multiple correlation coefficients (R2) which tells the level of variance in the dependent variable (customer satisfaction) that is explained by the model [22]. on customers" satisfaction at $95 \%$ confidence level. The significant service quality factors have been included for the establishment of the function. The established regression function is: $\mathrm{Y}=1.604+0.2$ $42 \times 1+0.012 \times 22+0.0211 \times 3+0.037 \times 4+0.05 \times 5$

The result of this study indicates that except empathy, all predictor variables or service quality dimensions (tangibility, reliability, responsiveness, and assurance) that make a statistically significant contribution on combined influence the satisfaction of customers. On the other hand, empathy has no significant effect 


\section{Annals of Social Sciences \& Management studies}

on customer satisfaction. The adjusted $\mathrm{R}^{2}$ of 0.827 indicates $82.7 \%$ of the variance in customer satisfaction can be predicted by the service quality offered by the branch municipalities. Therefore, service quality has a positive and significant effect on customer satisfaction $[23,24]$.

\section{Conclusion}

The main purpose of this study was to investigate the impact of service quality on customer satisfaction, the case of Nekemte Municipality specially land administration \& management office. The results of the descriptive statistical analysis also indicated that, customers were not satisfied with service qualities. About the ability of municipalities to provide service at the designed and promised time, customers were expressing their dissatisfaction over poor service. There is lot of complaints from customer about the poor network and frequent power interruption. Customers are not happy with the current Nekemte Municipality land administration \& management office performance expressing their disagreement towards poor quality service. Furthermore, the analysis of regression of the five factors of service quality with customer satisfaction was significant in all factors of service quality.

Finally, the correlation result shows that there is positive and significant relationship between tangibility, reliability, responsiveness, assurance and empathy and customer satisfaction. The finding also indicates that the highest relationship was found between responsiveness and customer Satisfaction, while the lowest relationship was found between empathy and customer satisfaction. Similarly, the multiple regression results showed that except empathy, the four service quality dimensions (tangibility, responsiveness, reliability, and assurance) have positive and significant impact on customer satisfaction. Therefore, high quality service is an increasingly important weapon to survive, the higher service quality, and the higher customer satisfaction. Therefore, Nekemte Municipality land administration \& management office should influence this dimension as a way of ensuring that their customers get the satisfaction, they expect in the services offered.

\section{Recommendation}

Based on the major findings and conclusion of the study the following recommendations were forwarded;

a) Managers should be aware that, among the various dimensions of service quality, Assurance was especially significant in fostering satisfaction for the customers of Nekemte Municipality in land administration \& management office. Assurance plays a key role in determining customer satisfaction implying that the technical aspects that management may leverage on to drive customer satisfaction are not of such importance to the customer. It is apparent that focusing on delivering high quality services and improve service quality effectively is critical for customer satisfaction.

b) In addition, the satisfaction of customers was significantly influenced by the Assurance and Reliability. It is thus apparent that Nekemte Municipality particularly land administration \& management office could make assessing and monitoring service quality periodically, to enable the Factory to identify where improvements are needed from the customers' view point, and to place an emphasis on the underlying dimensions of service quality, especially on Assurance, and should start with improving service quality in order to raise customer satisfaction.

c) Generally, Management of Nekemte Municipality land administration \& management office should keep track of the changes in perceptions and expectations of their customers. As indicated above this study indicates Assurance was the most important driver of service quality whereas according to the literature review reliability was the most important driver of service quality. These findings therefore indicate that management needs to keep abreast with the changes in perceptions and expectations. This will enable Nekemte Municipality land administration \& management office to leverage on those key aspects that drive customer satisfaction and build loyalty.

\section{References}

1. Mik Wisniewski (2001) Assessing Customer Satisfaction with Local Authority Services Using SERVQUAL. Total Quality Management \& Business Excellence 12(7\&8): 995-1002.

2. Mik Wisniewski (2001) Using SERVQUAL to Assess Customer Satisfaction with Public Sector Services. Managing Service Quality 11(6): 380-388.

3. Rodríguez PG, Burguete JLV, Vaughan R, Edwards J (2009) Quality Dimensions in the Public Sector: Municipal Services and Citizen's Perception. Journal of International Review on Public and Nonprofit Marketing 6(1): 75-90.

4. Mohammad Mizenur Rahaman, Abdullah, Ataur Rahman (2011) Measuring Service Quality using SERVQUAL Model: A Study on PCBs (Private Commercial Banks) in Bangladesh. Business Management Dynamics 1(1): 1-11.

5. Sachdev SB, Verma HV (2004) Relative Importance of Service Quality Dimensions: a Multispectral study. Journal of Services Research 4(1): 93-116.

6. Zisis P, Garefalakis A, Sariannidis, N (2009) The Application of Performance Measurement in the Service Quality concept: The Case of a Greek Service Organization. Journal of Money, Investment and Banking 9: 21-47.

7. Frederick A Frost, Mukesh Kumar (2000) INTSERVQUAL-An Internal Adaptation of the GAP Model in a Large Service Organization. Journal of Service Marketing 14(5): 358-386.

8. Zeithaml VA, Parasuraman A, Berry LL (1990) Delivering Quality Service. New York: The Free Press. USA.

9. Berry LL, Zeithaml VA, Parasuraman A (1985) Quality counts in services too. Business Horizons 28(3): 44-52.

10. Bateson JEG, Hoffman KD (2011) Services Marketing International edition. ( $4^{\text {th }}$ edn), Canada: South Western Cengage Learning. pp. 277.

11. Bateson JEG (1995) Managing service marketing: text and readings. ( $5^{\text {th }}$ edn), Fort Worth: Dryden Press. pp. 50.

12. Naceur Jabnoun, Azaddin Khalifa (2005) A Customized Measure of Service Quality in the UAE. Managing Service Quality 15(4): 374-88. 


\section{Annals of Social Sciences \& Management studies}

13. Aaker DA, Kumar V, Day GS (2004) Marketing research. ( $8^{\text {th }}$ Edn), New York: Wiley, ACTS see South Africa, p. 565.

14. Friedman LG (2002) Go-to market strategy: advanced techniques and tools for selling more products, to more customers, more profitably. Boston: Butterworth-Heinemann. p.78.

15. Gabbott T, Hogg G (1998) Consumer and service. England: Wiley. p. 26.

16. Gall MD, Birg WR, GakkJP (1996) Educational research: An introduction. ( $6^{\text {th }}$ Edn), White plain, NY: Longman. p. 289.

17. Anand Kumar Jaiswal (2008) Customer Satisfaction and Service Quality Measurement in Indian call centers. Managing service quality 18(4): 405-416.

18. Don Scott, David Shieff (1993) Service Quality Components and Group Criteria in Local Government. International Journal of Service Industrial Management 4(4): 42-53.

19. Eugene Sivadas, Jamie L Baker-Prewitt (2000) An examination of the relationship between service quality, customer satisfaction, and store loyalty. International Journal of Retail \& Distribution Management 28(2): 73-82.

20. Sureshchandar GS, Rajendran C, Kamalanabhan TJ (2001) Customer Perceptions of Service Quality: A Critique. Total Quality Management 12(1): 111-124

21. Tan KC, Kek SW (2004) Service quality in higher education using an enhanced SERVQUAL approach. Quality in Higher Education 10(1): 1724.

22. Gregg G Van Ryzin (2004) The measurement of overall citizen satisfaction. Public Performance and Management Review 27(3): 9-28.

23. Wan Zahari Wan Yusoff, Maziah Ismail, Graeme Newell (2008) FMSERVQUAL: a new approach of service quality measurement framework in local authorities. Journal of Corporate Real Estate 10(2): 130-144.

24. Mik Wisniewski, Donnelly M (1996) Measuring Service Quality in the Public Sector: The Potential for SERVQUAL. Total Quality Management 7(4): 357-365.

DOI:10.19080/ASM.2019.04.555629 
